\title{
地域連携活動における農村地域サテライトの役割と課題
}

\author{
内平 隆之（神戸大学大学院農学研究科） \\ 中塚 雅也（神戸大学自然科学系先端融合研究環）
}

\section{The Role of University Satellites in Rural Areas for Promoting Regional Partnerships}

\author{
Takayuki Uchihira (Kobe University) \\ Masaya Nakatsuka (Kobe University)
}

Rural areas are facing serious problems of aging and depopulation, and universities are expected to play an active role in supporting and activating these areas. This study explores the roles and achievements of four university satellites in rural areas. By conducting interviews on (1) the process of their foundations, (2) their activities, (3) their management systems, (4) their achievements and challenges, and (5) the roles of their resident officers, the

\section{1. はじめに}

\section{(1) 研究の背景と目的}

近年, 大学の第 3 の役割として社会貢献が求めら れている. 農村地域では, 都市と農村の協働の推進や, 地方再生や農村の活性化の担い手として大学の貢献 が期待されている ${ }^{1)}$. 特に, 過疎・高齢化が進む農村 地域の現状を鑑みると, 地域の課題解決を大学が教 育・研究・社会貢献を通じて支援していくことが必 要であろう.さらには, 大学が農村地域のサポーター や地域活性化の担い手として, 直接的・間接的に関 与することへの期待も更に高まると思われる.

そのためには, 長期的な地域参画型の教育・研究 を実施する仕組みが求められ, 近年では大学本体と は離れた農村地域に地域連携拠点を設立する動きが 拡がっている.

本稿では, 農村地域に打忊る大学の教育・研究拠 点であり, 研究蓄積に乏しい「農村地域サテライト」 に着目して，この拠点の実態を明らかにするととも に, その運営の特徵と果している役割, 課題を考察 することで，農村地域に和ける地域連携拠点のあり 方を示すことを目的とした。

な报,ここでいら農村地域サテライトとは, 大学・ reliability, interactivity, and ripple effects of the satellites are analyzed. To enable and maintain regional partnerships, support systems from local governments, network platforms, local organizations, and universities are needed. In rural areas, university satellites provide reliability through resident officers, interactivity through educational projects, and ripple effects through lifelong education, all of which are directly related to regional needs.

大学院の本部から地理的に離れた農村地域に設置さ れた大学と関連した拠点とする ${ }^{2)}$.

\section{（2）地域連携活動の課題}

農村地域に打ける地域連携活動の課題は既往研究 ${ }^{3)}$ から, 以下の 3 点に整理される. (1)信頼関係の構築: 農村と大学，それぞれのルールや習慣，人間関係等 を互いに理解し，信頼しあら関係をつくる，連携活 動が一過的なものとなり信頼を失うといら問題の解 決飞含む. (2)相互効果の促進 : 農村の地域課題解決 や人材育成と, 大学の教育研究との相互効果を高め る. 農村の現場への研究者の往来を促進する支援方 法の確立や, 地域課題の解決につながった固有の知 見に対する研究評価，社会貢献に対する教員評価の 改善も含屯. (3)普及システムの構築 : 特定地域との 連携で生み出された知財を地域全体に普及させる仕 組みの構築である．大学は知財や成果を活用する担 い手にはなりにくく，連携の成果を活用し普及させ る主体形成が重要な課題となる。 また研究者個人の 個別専門性では, 知の実用性に限界がある, さらに, 長期的連携体制の未整備 ${ }^{4}$ や，連携成果の地域への 普及が困難となっている問題を含む.

本研究では, 以上のように地域連携活動で課題と 
なっていた，(1)信頼関係の構築(2)相互効果の促進(3) 普及システムの構築の 3 点に着目し, 農村地域サテ ライトの役割と課題について考察する.

\section{（3）研究の方法}

事例対象は，駐在員が括り日常的な拠点運営が行 われている農村地域サテライトとした ${ }^{5}$. 対象の選 定方法は, 各大学のホームページ等を参照し, 電話・ メールで確認する方法で行った。調査方法は，2010 年 9 月に各農村地域サテライトを訪問し, 駐在員と 運営関係者にヒアリングと関連する資料收集であ る. 調査項目は，1）サテライト設置の経緯，2）取 組の内容，3）運営の仕組み，4）拠点の実績と課題,

5）駐在員の意義である.

\section{2. 大学研究者と農村の地域連携の枠組み}

既往研究や HP 等の資料調査から, これまでに行 われてきた大学研究者と農村の連携の枠組みを表 1 に整理した．個別研究者の社会貢献の限界を越光る ためには，組織的推進体制を確立する必要がある6). そのため, 様々な取組が試みられているが，その推 進体制は大学機構との関係, 拠点の立地から 4 つに 区分できる.

\section{（1）大学機構外の推進体制}

まず，大学機構外の推進体制について整理する. 大学研究者が, 農村地域で積極的な社会貢献を行う ために，大学機構の外に拠点を設置し活動する事例 がある. 都市地域には、これまでに大学研究者が関 与する NPO 法人やコンサルタントが，農村地域を 支援するために設置されてきた。農村地域に沶いて も, 官学等の連携を通じた連携型地域シンクタンク を設置する動きがある。具体的には，行政の出資に より設立された島根県中山間地域研究センターや, 教員出資による (株) 愛媛地域総合研究所等である. 組織的貢献を図るために設置され実践的な研究 7) も 進められている.

\section{表 1. 研究者が関与する組織的推進体制の区分}

\begin{tabular}{|c|c|c|}
\hline & 大学機構外 & 大学機構内 \\
\hline 都市地域 & $\begin{array}{l}\text { ・NPO 法人 } \\
\text { ・コンサルタント } \\
\text { ・シンクタンク }\end{array}$ & $\begin{array}{l}\text { • 大都市型大学地域連携部 } \\
\text { 門 }[1]\end{array}$ \\
\hline 農村地域 & ・連携型地域シンクタンク & $\begin{array}{l}\text { - 地方都市型大学地域連携 } \\
\text { 部門 }[1] \\
\text { (@)農村地域サテライト }\end{array}$ \\
\hline
\end{tabular}

\section{（2）大学機構内の推進体制}

次に，大学機構内の推進体制について整理する. 大学組織内に農村地域での社会貢献推進体制を確立 するために，産学連携・地域連携推部門を設置する 動きが活発である ${ }^{8)}$. 大学内に担当空口と専任・兼 任の担当教員・研究員を配する動きもみられる.

大学の地域連携を考光る上で, 地方都市型大学(農 村地域）と大都市型大学（都市地域）の区分が必要 とされる ${ }^{9}$. 地方都市型大学地域連携部門は，地元 に立地する大学に対する地域からの信頼感が強く大 学々農村の長期的連携に進展する素地は十分ある. 一方で，大都市型大学地域連携部門については，周 辺部に農村を抱えていない特性上，特定の農村との 協働といら縛りはないが，協働相手の選択を教員の 人的ネットワークに依存する場合が多い，加えて学 生にも農村との繋がりがない場合，一過性の連携に 終わる課題があげられている.

大都市型大学・地方都市型のいずれにしても, 連 携の成果は大学内部と受入集落に限定的になりやす い，確かに，教員が個別に社会貢献を行っていた時 代よりは推進体制が確立して抢り，その成果を還元 するために，フォーラムや HP 等を通じて発信する 仕組みがある。しかし，受入集落外の地域に成果や 知財を普及させるシステムについては未確立である.

そらしたなかで, 近年, 農村地域サテライトの設 置が活発である。いうまでもなく，既に中心市街 地の活性化や子育て支援を目的に，都市部の市街地 にサテライトを設置する動きがあった ${ }^{10)}$.このよう な拠点を農村部に設置し，農村地域と長期的な連携 体制を構築し, 地域課題解決と, 特色ある教育研究 に積極的に取り組む動きが活発となっている。

\section{3. 事例サテライトの取組}

次に, 調査事例とした 4 つの農村地域サテライト の組織概要や活動実績, 駐在員の役割, 取組の実績 と課題などを述べる。 また，表 2 はそれらを比較整 理したものである。

\section{（1）和歌山大学紀南サテライト}

設置の経緯は, 紀南地域に高等教育機関がなく, 地域の要請に応える形で 2005 年に設置された拠点 である. 大学の研究・教育機能やシンクタンク機能 を活用して，紀南の地域づくりに貢献するための「 大学の地域ステーション」を目指している. 
地域の支援体制は，地域シンクタンクである「き のくに活性化センター」と部屋をシェアし, 地域や 自治体と連携事業を行っている.

特徵は，現地で経済学修士の取得できることであ る. 実績として, 経済学研究科南紀熊野サテライト コースにはのベ 185 名の受講があり, 毎年 1 名以上 の進学がある. 地域内の社会人教育・生涯教育に貢 献している。また自治体の生涯学習事業と連携し ネットワークを形成して抢り, 駐在員が中心となり， 生涯学習計画の策定と推進に寄与している.

駐在員の役割は，教育プログラムに関する調整業 務や, 自治体の生涯学習事業の推進者のネットワー クづくり，地域シンクタンクと連携したまちづくり に関連した調査や事業計画の策定などである.
なお，課題と認識されているのは，(1)大学本体の 教育や研究とサテライト活動との相乗効果を高める こと，(2)地域や学内への活動成果の PR どである.

\section{（2）金沢大学能登学舎}

設置の経緯は，当初は地域と協働した生物多様性 の調査と里山の保全活動の拠点として，2006 年に 外部資金及び地元自治体の協力（小学校の廃校舎の 借り受け）により設置された拠点である．設置を契 機に，「能登里山マイスタ一養成プログラム」を始 めとした, 人材育成や交流, 研究プロジェクトが次々 と発足し，多面的な活動をしている.

地域の支援体制は，以下に示す体制となっている. 駐在員 5 名や受講生の活動を，地域のリーダーであ るベテラン指導員 3 名が補佐し，マイスタ一支援

\section{表 2. 各農村地域サテライトの概要}

\begin{tabular}{|c|c|c|c|c|}
\hline & 和歌山大学紀南サテライト & 金沢大学能登学舎 & 神戸大学篠山フィールドステーション & $\begin{array}{l}\text { 地域拠点型農学エクステンションセンター (主幹校: 北海道大学) } \\
\text { 富良野サテラン }\end{array}$ \\
\hline 開設 & 2005年 & 2006年 & 2007年 & 2008年 \\
\hline 所在地 & 和歌山県田辺市 & 石川県珠洲市 & 兵庫県篠山市 & 北海道富良野市 \\
\hline 経緯 & $\begin{array}{l}\text { 紀南地域には, 高等教育機関がなく, } \\
\text { 地域の悲願であったこ域の } \\
\text { 高等教育・生涯教育の拠点として05年 } \\
4 \text { 月に設置. }\end{array}$ & $\begin{array}{l}\text { 生物多様性の調査と里山の保全活動 } \\
\text { の拠点として06年10月に設置. 三井物 } \\
\text { 産環境基金の支援により里山里海自 } \\
\text { 然学校を開講. }\end{array}$ & $\begin{array}{l}\text { 神戸大学農学部の前身である兵庫農科 } \\
\text { 大学が設置されてきた. 地域の新しい } \\
\text { 価値を創し,地域課題の解決と大学 } \\
\text { 教育研究の充実を図るための活動拠点 } \\
\text { として設置. }\end{array}$ & $\begin{array}{l}\text { 7〜8年前に研究者の集まりである研究会が } \\
\text { シンポを行ったのが縁. 北海道大学のサス } \\
\text { テイナピリティ学教育センターと農学研究 } \\
\text { 院の共同で設置. }\end{array}$ \\
\hline $\begin{array}{l}\text { 主たる } \\
\text { 専門 }\end{array}$ & 経済学系 & 生態学系(体制としては学際的) & 農学系 & 農学系 \\
\hline 取組内容 & $\begin{array}{l}\text { 高等教育部門:経済学研究科南紀熊 } \\
\text { 野サテライトュース等 } \\
\text { O地域研究生崖学習部門:地域課題研 } \\
\text { 究の実施, 公開講座 } \\
\text { 地域連携産官学連携部門:計画策定 } \\
\text { 支援, 地域づくりへの参画 }\end{array}$ & $\begin{array}{l}\text { O能登半島, 里山里海自然学校 (H21 } \\
\text { 地域関係者・NPOと運営委員会方式) } \\
\text { 能登里山マイスター養成プログラム } \\
\text { ○の半島里山里海アクティビティ } \\
\text { ○能登いきものマイスター養成講座 }\end{array}$ & $\begin{array}{l}\text { 共同研究 } 2 \text { 題 } \\
\text { 教育GP・食農コープ教育 } \\
\text { 地域ブランドづくり・まらづくりの } \\
\text { 支援 } \\
\text { オオフィスアワー等で相談対応 } \\
\text { ○地域向けセミナーを年3回実施. }\end{array}$ & $\begin{array}{l}\bigcirc \text { 戦略的大学連携事業の } 1 \text { 拠点 } \\
\text { 人材育成と社会貢献を循環的に進めるこ } \\
\text { とを目指す } \\
\text { 地域戦略の支援 } \\
\text { 消費者・企業連携の支援 } \\
\text { 内発的地域つくくのの支援 }\end{array}$ \\
\hline 運営 & $\begin{array}{l}\text { 学内, 地域創造支援機構推進会議拉よ } \\
\text { び地域連携・生涯学习習センター企画運 } \\
\text { 営委員会によって経営. }\end{array}$ & $\begin{array}{l}\text { 「金沢大学里山里海プロジェクト」が } \\
\text { 運営. 地域連携推進センーは事務的 } \\
\text { 支援のほか, 「地域連携コーディネー } \\
\text { ター」として2名の客員教授 (非常駐) } \\
\text { をプロジェクト全体の調整役・地元と } \\
\text { の仲介役として任命. }\end{array}$ & 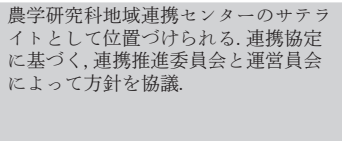 & $\begin{array}{l}\text { 地域関係者によって組織された富良野サテ } \\
\text { ライト運営委員会 }\end{array}$ \\
\hline 駐在員 & $\begin{array}{l}2 \text { 名 } \\
\text { (特任助教1名) } \\
\text { (地域連携コーディネーター) }\end{array}$ & $\begin{array}{l}\text { 6名 } \\
\text { (里山マイスター:特任助教3名, 教務 } \\
\text { 補佐員2名, 里山里海アクティビティ } \\
\text { は協働ディレクター(研究員) 1名) }\end{array}$ & $\begin{array}{l}\text { 2名 } \\
\text { (地域連携研究員2名) }\end{array}$ & $\begin{array}{l}\text { 1名 } \\
\text { (博士研究員1名) }\end{array}$ \\
\hline $\begin{array}{l}\text { 地域の } \\
\text { 支援体制 }\end{array}$ & $\begin{array}{l}\text { サテライト連絡協議会 } \\
\text { きのくに活性化センターとの連携 }\end{array}$ & $\begin{array}{l}\text { 地元ベテラン指導員 } 3 \text { 名現地 } \\
\text { マイスター支援ネット } \\
\text { 里山駐村研究員制度 } \\
\text { NPOおらっちゃの里山里海と共同運営 }\end{array}$ & (財)丹波の森協会と拠点をシェア & $\begin{array}{l}\text { 富良野市農林課啒託職員1名 } \\
\text { サテライト研究員 } 2 \text { 名※市職員当職 }\end{array}$ \\
\hline 主な実績 & $\begin{array}{l}\text { 南紀サテライトで経斎学修士が取 } \\
\text { 得可能(のべ185名が受講) } \\
\text { 学部開放授業 } 257 \text { 名 } \\
\text { ○生涯学習事業のネットワーク形成 } \\
\text { 各種調查・計画の策定支援 }\end{array}$ & $\begin{array}{l}\bigcirc 84 \text { 名のマイスター受講生を受入 } \\
\text { ○里山マイスターを } 26 \text { 名認定 } \\
\text { ○県外から } 13 \text { 名を受入 } \\
\text { ○就農希望者を } 22 \text { 名受入 } \\
\text { ○里山マイスター支援ネットの発足 } \\
\text { ○「地域づくり連携定」(07年7月)を } \\
\text { 締結し,受講生や講師を派遣したり, } \\
\text { 県外者の定住サポートを行う }\end{array}$ & $\begin{array}{l}\text { ○協議の上, 毎年, 地域課題, 政策テー } \\
\text { マ研究を } 1 \text { 題づつ実施. } \\
\text { 年 } 40 \text { 名程度学生が演習に参画. } \\
\text { 赤じゃが等の地域の新ブランドづく } \\
\text { りに貢献 } \\
\text { 年間100件程度の相談を処理 } \\
\text { 毎年 } 2 \sim 3 \text { 程度の学生が卒業研究を実 } \\
\text { 施 }\end{array}$ & $\begin{array}{l}\text { 以下の富良野サテライトの成果 } \\
\text { ○食の安全・安心基盤学演習11名春夏秋 } 3 \text { 期 } \\
\text { (1期 } 5 \text { 日間の演習) } \\
\text { ○安全安心マイスター8名育成中 } \\
\text { ○直売所の設置や,流通チャンネルの開拓 } \\
\text { を通じた地産地消の社会実験 }\end{array}$ \\
\hline $\begin{array}{l}\text { 当事者の } \\
\text { 課題認識 }\end{array}$ & $\begin{array}{l}\text { O地域研究・教育のための本学の学生 } \\
\text { と地域とのコーディネート } \\
\text { 地域へのPRと学内認知 } \\
\text { 地域課題解決の拠点づくり } \\
\text { 教育から研究へ }\end{array}$ & $\begin{array}{l}\text { ○金沢大学へのフィードバックとメ } \\
\text { インストリーム化 } \\
\text { ○地域をあげた継続体制の構築 } \\
\text { ○駐在員の研究エフォートの確保 } \\
\text { ○奥能登地域全体への成果浸透 } \\
\text { ○農業部門の振興 }\end{array}$ & $\begin{array}{l}\text { ○駐在員の雇用経費の確保 } \\
\text { ○篠山外の地域との連携強化 } \\
\text { 地域の人材坛成機能の構築 } \\
\text { 地域への成果の認知と普及 }\end{array}$ & $\begin{array}{l}\text { ○大学間・サテライト間・大学とサテライト } \\
\text { 間の情報共有に課題 } \\
\text { 補助事業後の推進予算が未定 } \\
\text { サテライト研究員が当職であり数年で交 } \\
\text { 代してしまい }\end{array}$ \\
\hline $\begin{array}{l}\text { 駐在員の } \\
\text { 役割 }\end{array}$ & ○顔をつなぐコーディネート機能 & $\begin{array}{l}\text { ○顔をつなぐコーディネート機能 } \\
\text { プログラムの推進 } \\
\text { ○常駐駐在員が受講生を指導 }\end{array}$ & $\begin{array}{l}\text { ○顔をつなぐコーディネート機能 } \\
\text { ○連携のスクリーニング } \\
\text { ○コミュニーションの場づくり }\end{array}$ & $\begin{array}{l}\text { ○機動性の高いコーディネート機能 } \\
\text { 計画者であり実践者である } \\
\text { ○コンサルタント活動の実施 }\end{array}$ \\
\hline 備考 & $\begin{array}{l}\text { 地域の高等教育・生涯学習の実践が特 } \\
\text { 徵的である.また, 唯一地域コーディ } \\
\text { ネーターの人件費が恒常的に確保さ } \\
\text { れており,補助金に依存していない. }\end{array}$ & $\begin{array}{l}\text { 就農, 起業の支援体制の確立が特徵. } \\
\text { また, 他団体受入による地域からの情 } \\
\text { 報発信と, 研究者受入による地域研究 } \\
\text { 拠点としての機能を発揮. }\end{array}$ & $\begin{array}{l}\text { 大学本体の研究・教育との密接な関係 } \\
\text { のるとで, サテライトの取り組みが行 } \\
\text { われている. }\end{array}$ & $\begin{array}{l}\text { 大学院教育と社会人教育を両立する人材養 } \\
\text { 成プログラムを実施 } \\
\text { 富良野市から共同研究費がサテライトにつ } \\
\text { いており駐在員の研究面を支援 } \\
\end{array}$ \\
\hline
\end{tabular}


ネット（農林漁業者による支援組織）と里山駐村研 究員（民間人材ネットワーク）がサポートする体制 である，この体制により，人材養成と知の移転を図 かり，大学と地域の知の普及を実現している.

実績は, 能登地域で新規就農や起業を目指す社会 人を対象に 4 年間で 84 名のマイスター受講生を受 入れたことである. 現在 26 名のマイスターを認定 している. 県外から 13 名を受け入れ, 就農希望者 を 22 名受け入れるなど，地域の新たな担い手の育 成江貢献している。

駐在員の役割は, 主に各プログラムの推進と, 受 講生の担任として, 新規就農・起業や地域課題解決 等をテーマとする卒業論文の指導等である. 受講生 が研究テーマを選択し, 研究者が支援することで, 地域からのニーズに応觉る成果をあげている.

課題と認識されているのは, (1)大学本体の教育や 研究とサテライト活動との相互効果を得ること, (2) 地域や学内への活動成果の PRすること, (3)補助金に 依存しない地域をあげた継続体制の構築 ${ }^{11}$ 等である.

\section{（3）神戸大学篠山フィールドステーション}

設置の経緯は, 地域課題の解決と大学教育・研究 の充実を目指し 2007 年に設置された拠点である. 篠山市にとは神戸大学農学部の前身となる兵庫農科 大学があった縁がある。

地域の支援体制は, 篠山市との連携協定に基づき 連携推進委員会と運営員会によって方針を協議する 体制である.ささらに地域の財団法人丹波の森協会と 拠点をシェアしている.

特徵は, 学部教育と研究に関連した実績があがっ ている点である. 研究面に関しては, 地域課題に関 連する研究と政策課題に関する研究を毎年一題ず つ, 教員と行政担当課, 地域関係者からなる研究グ ループをつくり実施している. 具体的には, 丹波黒 大豆, ナレッジマネジメント, 地域ブランドの育成 等のテーマで実施されている，教育面に扔いては， 食農コープ教育プログラム ${ }^{12)}$ の実践フィールドと して毎年 40 名の学生が「農業農村フィールド演習」 や「農業農村プロジェクト演習」, インターンシップ, ボランティアなどを通じた農村地域での体験学習を 行っている. その活動の一部は卒業研究等にもつな げられ, 生物多様性を保全する湿地づくりや, 大学 提供の新品種による新しいブランド農産物づくりが 具体的にすすめられている.
駐在員の役割は，演習の事前調整，連携や知財の 普及(新品種の栽培法) 飞関する相談業務等である. 相談は年間 100 件程度あり, 学外からの地域作り関 連の七ミナ一室の利用は, 年間 35 回あるなど, 有 意義な情報交換・相談・雑談の場となっている.

課題と認識されているのは, (1)駐在員の雇用経費 の確保，(2)篠山以外の地域との連携強化，(3)地域の 人材養成機能の構築, (4)地域一の連携成果の認知と 普及等である。

\section{（4）地域拠点型農学エクステンションセンター富良 野サテライト}

設置の経緯は, 戦略的大学連携事業の一拠点とし て, 2009 年に北海道サスティナブル学教育センター と農学研究科の共同で設置された拠点である.

地域の支援体制は，市農林課嘱託職員 1 名とサテ ライト研究員として市職員 2 名となっている.

特徵は, 大学院教育と社会人教育を連動させた食 の安全・安心に関わる人材育成プログラムである. 富良野サテライトでは大学院教育である「食の安全 安心基盤演習」の 11 名の受講生を受け入れ春夏秋 3 期に 1 期 5 日の演習を行なって拈り大学院教育に貢 献している。また富良野の社会人を対象に安全安心 マイスター8名を現在育成して和り, 安全安心をキー ワードとした地域ブランド向上に貢献している.

駐在員の役割は, 演習や研究等のコーディネート 機能の他に, 地域の計画策定のコンサルタント業務 等である、計画の立案面から協力し，それを実践し ている. 具体的には, 地産地消を推進するための, 直売所の設置運営，流通チャンネルの確立等の社会 実験等である。研究面については富良野市から共同 研究費がサテライトについている.

課題となっているのは, (1)大学とサテライトの情 報共有，(2)補助事業後の予算の確保等である.

\section{5. 考察}

\section{（1）運営特性}

発足経緯については, 地域からの要請, 研究・教 育拠点として設置, 研究者の個人的関係を基盤に発 展したものなどに整理できる. 主たる専門分野は, ぞのような知財を地域に提供しているかを知る上で 重要な区分である. 生態学系・農学系・経済系の 3 つとなっている. 取組の内容については，大学の強 みである教育力を活かし，人材養成を中心事業とし 
ていること，その育成の対象は，学部教育，大学院 教育, 社会人教育, 高等 - 生涯教育々成人教育の領 域をカバーしていることが特徵である。また，地域 課題解決研究に取り組反計画の策定や地域づくりの 実践するサテライトもある. サテライトは学内の地 域連携部門に位置づけられるものが多く，地域との 運営員会での合意に基づき事業が実施されている が, 実質的な推進を担う駐在員は 1 名〜 6 名である.

また，いらまでもなく農村地域サテライト単独で は, 実効的な地域課題解決は困難である。そのため, 事例とした農村地域サテライトでは, 次のような運 営上の工夫をしていることが分かった.

第 1 は，市の職員や地域のリーダーなどが助言・ 協力するプロジェクトの後見人体制の確立である. 金沢大学能登学舎の事例では, 農業・漁業・林業の 各地元ベテラン指導員を委嘱して里山マイスター （社会人教育）育成に貢献している. 第 2 は, 連絡 協議会や現地マイスター支援ネットなど，連携事業 のステークフォルダとの意見交換の場の設置であ る. これにより地域の課題や連携事業の課題に対し て幅広い協力や広報面や財政面での支援を得ること ができている. 第 3 は, 地域組織とサテライトの連 携体制の確立である. 具体的には. 地域のコンサル タント, NPO, 活性化センター等と拠点をシェア しながらの連携事業の推進である。これは，すべて の地域課題解決の担い手にはなれないといら大学の 欠点を補ら上でも重要であり, このことにより地域 課題を解決と連携成果の普及を効果的に扣こならこ とが可能となっている. 第 4 は, サテライトが必要 とする資源や知財や情報を大学本体の地域連携部門 が支援する体制の確立である。地域連携部門に専門 教員や職員を設置し, 補助金の獲得や大学側の研究 チームの組織化, 駐在員が必要な資源の把握等が行 われている。

\section{(2) 役割}

次に, 信頼関係の構築, 相互効果の促進, 普及シ ステムの構築の 3 つの課題について, サテライトが 果たしている役割を考察する.

まず，信頼関係の構築についてである．地方都市 型大学連携部門と同様に地元に施設があることで, 農村側の信頼感と長期的な連携活動への期待が得や すい.ささらに駐在員がいることで，大学と地域の相 互の要求や課題を顔の見える関係の中で頻繁に調整
できる．特に受入側集落の心理的不安の緩和や相談 対応なぞで信頼関係の構築に大きく貢献している. また，駐在員の信用で，学生の受け入れ先となる農 家や企業との調整が行わ玌ている．以上の点でサテ ライトは信頼関係の構築に寄与しているといえる.

次に, 相互効果の促進についてである. 大学が求 める学生教育と, 社会人教育を両立させる事例や, 新たな産品の開発をともに行ら事例等，駐在員が調 整役となり，相互効果が得られている。 また，連携 活動に関与した学生の卒業研究の実施や，卒業研究 と関連した地域プロジェクトが実施されるなど，地 域活性化の一助となる相互効果がある。さらに，駐 在員が, 研究者や学生の農村地域での研究相談や, フィールド仲介をして拉り, 相互の理解を高め, 研 究者の地域課題の把握の円滑化に貢献している.

最後に，普及の仕組みづくりについてである。駐 在員自身が核となり，地域組織と連携し，計画等へ のコンサルタント的に関与し，立案した計画の策定 を進め, その担い手として計画の実践を行うなど, 地域連携成果の普及事例が確認できた。 また，地域 の生涯学習・社会人教育の施設として活用されて掠 り，大学の知を普及する仕組みもある．さらに，社 会人教育の卒業生を核に地域に新たな人材ネット ワークが形成され，地域の知を活用する新たな主体 育成に貢献している。 この地域の人材養成の仕組み は，大学の知財を地域に広く普及させる仕組みとし ても高く評価できる.

\section{6. 今後の課題}

最後に，現状の農村地域サテライトの課題を整理 し，今後のあり方についての展望を述べる.

まず，サテライトでの「場」の生成 ${ }^{13)}$ をさらに 促進させる必要がある。現状は，七ミナー等の学習 の場としての側面が強い，地域課題解決・価值創造 を進めるためには，地域の情報や人材の結束点であ り，地域課題に対するコンセンサスを形成する場が 生成される必要がある。特に駐在員には，大学と地 域の相互作用を生み出すためのチャンネルを選別す る役割が重要である。この仕組みを有効に機能させ るには，目的に応じて，その相談役や後見人となる 地域人材の取り込及と, 連携協力団体のネットワー クづくりを進めるといら地域体制も必要である。さ らに，学内でも駐在員と大学内の地域連携部門とが 


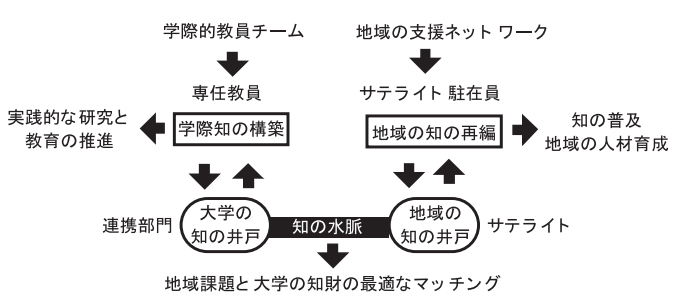

図 1. 農村地域サテライトの役割

緊密に連携し, 大学の多様な知財や教員にアプロー チし, 分野横断的な場を生成することも求められる.

次に, 実施体制を安定化する必要がある. 現状で は多くが補助金を頼りに進めて和り，予算等が恒常 化されていない，大学内での地域貢献に関する評価 も定まって扣らず，特に駐在員の雇用経費もほとん ぞ補助金頼みである ${ }^{14)}$. サテライトの機能と負担を 地域と大学で検討してくことも課題である.さらに, 大学内でも, 大学プロジェクトとしての明確な位置 ら゙けることや, 駐在する研究者のキャリアパスを構 築することが課題である ${ }^{15)}$.

以上のように, 課題は多く残るものの, 農村地域 サテライトの設置は, 大学の教育・研究と, 社会貢 献が三位一体となった連携活動を更に推進するもの として期待される。 また，こうした効果を更に高め るためには, 地域課題を解決する研究と, 大学拉よ び地域の人材の育成を結び合わせた取組を拡げるこ とが重要であり, 今後のサテライト運営の核とすべ きと考光る.

農村地域サテライトは, 各農村地域に打いて大学 から知を汲み上げるいわば「知の井戸」である，相 互をつなぐ「知の水脈」が枯机ぬよう, 井戸の番人 として連携のチャンネルを管理し, 強化することが 駐在員に求められる. 今後, 駐在員がこうした機能 の発揮しながらサテライトの機能強化が進められる ことにより, 多くの地域と大学が「知の水脈」で繋 がることが望まれる.

注 1）たとえば, 文献 [1] では, 大学を農村地域を活性 化する担い手として位置づけており, 大学が有す る豊富な理論や技術, 学生特有の構想力, 中立的 立場といった「強及」を活用ために，農村との協 働のきっかけを提供することが重要であるとして いる. 特に同書 pp. 15-18 では, 積極姿勢を通じた 大学の魅力の向上のため, 農村との協働を実施す
る例が見られる。

2）新設でなくとも，大学外飞ある農場や演習林飞付 随する施設を拠点に, 社会貢献を進めている事例 がある (文献 [5])。これる農村地域サテライトと 同様の機能発揮が可能であると考えている. 本研 究では, アメリカの大学エクステンションセンター も農村地域サテライトとして位置ら゙ける。

3）文献 [1] には大学の弱及を6つ. 文献 [2]には, 農林経済教員の社会貢献の 4 つの限界をあげている.

4）ゼミ活動では，動員・資金・期間・目的に制約が ある.

5）駐在員がいることで, 教員・学生の地域の風習や 人間関係への理解が促進され，日常的な地域との 交流により地域社会との信頼関係の構築が進む. さらに, 日常的な地域活動への参加などを通じて, 地域のニーズにあった研究課題の発掘や, 駐在員 の専門性を活かした研究・実践活動が促進される ことが期待できる，そのため，駐在員がいるサテ ライトに絞って研究を進めた.

6) 文献 [3]

7）文献 [4] と文献 [5]. 筆者らは, このような組織 的運営体制整備には以下の課題があると考光た. それは，(1)出資確保，(2)地域の多様化に対応した 多様な専門性を確保するための雇用経費捻出, (3) NPO や民間のシンクタンク等との事業競合.

8）文献 [1] p. 15 飞は地域連携拠点を学内に設けて いる大学の一覽がある。農学分野に関して文献 $[3]$ に先の分類がある. 大学機構内の改編で設置可能 であるため, 大学機構外に推進体制を設置するよ り, 出資や経費が低く抑えられるメリットがある.

9）都市型大学と地方都市型大学の区分については文献 [1] p. 15-18 亿記載. 地域の特色を活かした研究な どを通じた地域内のプレゼンス向上への欲求の有無 や，周辺部に農村との関係からくる特定の農村との 協働の縛りの有無など, 連携条件や意図に違いがあ ることなどがその理由としてあげられている。

10）特に中心市街地の活性化の方法として普及してき た. 1996 年に関西大学の片寄ゼミが兵庫県三田市 の商店街に設置した「ほんまちラボ」など、また 文献 [6]のよらな研究がある.

11）金沢大学では, 奥能登の複数の自治体で各々数 十万程度の人件費を持ち合い, エリアのサテライ トとして位置ら゙雇用するなどの対策が検討され ていた. サテライトのない地域への成果の普及の 実証などが課題となるが，このよらな方式も費用 分担方法の一つとして検討の余地がある. 
12）文部科学省「質の高い大学教育推進プログラム」(平 成 20 年) に採択された神戸大学農学部が推進する 教育プログラム。

13）文献 $[7]$. イノベーションには実践的三段論法（目 的, 手段, 行動) が明確である必要があり, 明確 であればあるほど，まわりの人々と目的を共有し， ともに行動する場が生成される.

14）教育補助金の場合, 研究の実施は目的外となるた め, 雇用された駐在員の専門研究の実施に制限が 加えられる場合がある。

15）駐在員のキャリアアップのためには地域連携によ る研究成果の評価が課題となる. 地域課題解決に 資する科学へと特色ある研究を農村サテライトは 促進することが期待されるが，各種学会内での評 価は定まって扣らず議論が必要であろう。従来の フィールドワークを中心とした認識のための科学 から, 社会実験等を通じた実践科学へ, 地域課題 に応じた実践的研究の推進を, 農村サテライトの 設置は促進するものと期待できる.

\section{参考文献}

［1］都市と農村の協働の推進に関する研究会「都 市と農村の協働の推進に向けて」, 農林水産省, 2008.6.
[2]木村伸男「大学の農林経済教員の社会貢献と その意義・限界」『農林業問題研究 (第 165 号)』, 地域農林経済学会, 2007.3, pp. 17-23.

[3] 内平隆之・中塚雅也・加古敏之「農学分野に 扣ける地域連携の枠組又と展望一神戸大学大 学院農学研究科と篠山市の連携を中心に」『農 林業問題研究 (第 170 号)』, 地域農林経済学会, 2008.6, pp. 129-134.

[4] 中西敏雅「島根県中山間地域研究センターが 目指すもの：存続が危ぶまれる中山間地域社 会を前にして」『農業土木学会誌 67(5)』, 農業 土木学会, 1995.5, pp. 41-43.

[5]家串哲生「大学農林経済学教員の社会貢献の 役割を構造的視覚から探る」『農林業問題研 究 (第 165 号)』, 農林経済学会, 2007.3, pp. 41-42.

[6] 鵤心 治・中園畺人・小林剛士，「地方大学の まちなか研究室によるまちづくり活動と運営 に関する一考察」『日本建築学会技術報告集 (23)』, 2006.6, 日本建築学会, pp. 395-398.

[7] 野中郁次郎・勝見明『イノベーションの知 恵』, 2010.10, 日経 BP 社. 